\title{
PENINGKATAN RESPON KEBAL NON-SPESIFIK PADA IKAN LELE DUMBO (Clarias sp.) DENGAN PEMBERIAN IMUNOSTIMULAN ( $\beta$-GLUCAN)
}

\author{
Akhmad Rukyani*), Evi Silvia**), Agus Sunarto*) dan Taukhid")
}

\begin{abstract}
ABSTRAK
Imunostimulan merupakan alternatif untuk penggunaan vaksin dan antibiotik dalam perlindungan terhadap serangan penyakit ikan. Penelitian ini dilakukan untuk mengetahui dosis efektif imunostimulan yang dapat meningkatkan respon kebal nonspesifik pada ikan lele dumbo (Clarias sp.). Ikan uji dengan rataan panjang total $9 \mathrm{~cm}$ diberi pakan komersial yang telah dicampur imunostimulan masing-masing dengan dosis 500, 750, 1000 dan $1250 \mathrm{mg} / \mathrm{kg}$ pakan, serta tanpa penambahan imunostimulan sebagai kontrol. $\beta$-glucan diberikan selama 30 hari pemeliharaan. Pengujian peran imunostimulan terhadap respon kebal nonspesifik dilakukan melalui uji tantang terhadap infeksi bakteri Aeromonas hydrophila dengan jumlah $10^{5}$ cfulekor. Pengamatan dilakukan terhadap total leukosit, diferensial leukosit, titer antibodi, gejala klinis serta tingkat sintasan ikan setelah diuji tantang. Hasil penelitian menunjukkan tingkat sintasan sebesar $44,14 \% ; 83,33 \% ; 63,89 \% ; 41,67 \%$ dan $25 \%$, masing-masing untuk dosis $\beta$-glucan 500,750 , 1000, 1250 dan $0 \mathrm{mg} / \mathrm{kg}$ pakan (kontrol). Dengan persamaan kuadratik diperoleh dosis optimum sebesar $773,81 \mathrm{mg} / \mathrm{kg}$ pakan.
\end{abstract}

\section{ABSTRACT: Improvement of non-specific immune response of African catfish (Clarias sp.) by application of immunostimulant ( $\beta$-glucan). By: Akhmad Rukyani, Evi Silvia, Agus Sunarto and Taukhid.}

Immunostimulant may represent an alternative to vaccines and antibiotics in the protection of farmed fish against diseases. This study was done to evaluate the effective dose of immunostimulant ( $\beta$-glucan) to increase non-specific immune response of African catfish (Clarias sp.). Catfish fingerling with an average total length of $9 \mathrm{~cm}$ were treated with immunostimulant given through pelleted feed at 500;750;1000;1250; and $0 \mathrm{mg} / \mathrm{kg}$ (control). The immunostimulants were given daily for 30 consecutive days. The fish were then challenged with Aeromonas hydrophila at $10^{5} \mathrm{cfu} /$ fish to evaluate their non-specific immune response. The results showed that the survival rate of the catfish were $44.14 \% ; 83.33 \% ; 63.89 \% ; 41.67 \%$ and $25 \%$ at $500 ; 750 ; 1000 ; 1250$; and 0 $\mathrm{mg} / \mathrm{kg} \beta$-glucan respectively. The optimum dose of $\beta$-glucan determined by quadratic equiation was $773.81 \mathrm{mg} / \mathrm{kg}$ feed.

KEYWORDS: Immunostimulant, immune response, catfish.

\section{PENDAHULUAN}

Dalam budidaya perairan, ikan senantiasa hidup dalam lingkungan yang mengandung berbagai mikroba patogen seperti virus, bakteri, jamur dan parasit. Karenanya kasus kematian ikan sering disebabkan oleh sekaligus campuran antara berbagai patogen tersebut atau sulit diduga patogen mana yang akan menyerang.

Pengendalian penyakit ikan akan lebih efisien bila dilakukan melalui tindakan pencegahan antara lain dengan cara vaksinasi. Cara vaksinasi ini telah mulai dilakukan di Indonesia (Rukyani dan Nitimulyo, 1993; Supriyadi dan Rukyani, 1990; Rukyani et al., 1995), akan tetapi umumnya vaksin tidak mampu melawan beberapa penyakit bakteri dan virus sekaligus (Raa et al., 1992).

Tidak seperti halnya vaksin (antigen) yang memicu produksi antibodi spesifik terhadap satu patogen tertentu, sekelompok senyawa biologi dan sintetis yang disebut imunostimulan dapat

\footnotetext{
*) Peneliti pada Balai Penelitian Perikanan Air Tawar, Sukamandi

**) Fakultas Perikanan, Institut Pertanian Bogor
} 
meningkatkan pertahanan nonspesifik (Fenichel dan Chirigos, 1984 dalam Robertsen et al., 1990). Oleh karena itu, imunostimulan dapat dijadikan alternatif untuk penggunaan vaksin dan antibiotik dalam perlindungan terhadap serangan penyakit (Robertsen et al., 1990).

B-Glucan merupakan salah satu imunostimulan yang terbuat dari dinding sel cendawan Saccharomyces cerevisiae dan telah terbukti mampu merangsang dan mengaktifkan mekanisme pertahanan non-spesifik pada berbagai organisme tingkat tinggi seperti tanaman, vertebrata dan avertebrata (Raa et al., 1992). Cara penggunaan imunostimulan memiliki pola yang sama dengan penggunaan antibiotik atau bahan kimia, namun belum banyak petunjuk yang jelas tentang sediaan dan efektivitas imunostimulan selama dan setelah pemakaian (Anderson, 1992).

Diduga mekanisme kerja imunostimulan adalah dengan cara meningkatkan aktivitas oksidatif netrofil, memperbesar kegiatan sel-sel fagosit seperti makrofag dan limfosit $\mathrm{T}$ atau daya kerja sel sitotoksik lainnya, serta menginduksi proteinprotein sitokin seperti interleukin, interferon, faktor nekrosis tumor, protein C-aktif komplemen dan lisosim (Fletcher, 1982). Penelitian ini bertujuan untuk mengetahui dosis efektif penggunaan glukan melalui ransum pakan bagi peningkatan ketahanan tubuh ikan lele dumbo (Clarias sp.).

\section{BAHAN DAN METODE}

Ikan uji yang digunakan adalah lele dumbo dengan panjang total rata-rata $9 \mathrm{~cm}$, dipelihara dalam akuarium berukuran $60 \times 40 \times 35 \mathrm{~cm}^{3}$ dengan dengan kepadatan 30 ekor/akuarium. Aklimatisasi dilakukan selama 2 minggu, dan pergantian atau penambahan air sebanyak $10-20 \%$ total volume dilakukan setiap minggu.

Rancangan percobaan yang digunakan pada penelitian ini adalah rancangan acak lengkap (RAL) dengan dosis penambahan glukan ke dalam pakan sebagai perlakuan, masing-masing dengan 3 ulangan.

Imunostimulan yang digunakan adalah Macro Gard $\beta$-Glucan (glukan) diproduksi oleh Biotec Mackzymal Norwegia. Pada penelitian ini diterapkan 5 dosis penambahan glukan pada pakan, yaitu (A) tanpa pemberian imunostimulan (kontrol), (B) $500 \mathrm{mg} / \mathrm{kg}$ pakan, (C) $750 \mathrm{mg} / \mathrm{kg}$ pakan, (D) $1000 \mathrm{mg} / \mathrm{kg}$ pakan dan (E) $1250 \mathrm{mg} / \mathrm{kg}$ pakan. Ransum pakan yang ditambah dengan imunostimulan diberikan selama 30 hari pemeliharaan. Pakan diberikan sebanyak 5\% bobot tubuh ikan dengan frekuensi pemberian sebanyak tiga kali per hari, yaitu pada pukul 07.00, 12.00 dan 17.00 .

Bakteri yang digunakan untuk uji tantang adalah Aeromonas hydrophila isolat 26 koleksi Balitkanwar. Untuk memulihkan virulensi bakteri, dilakukan uji Koch Postulat (reinfeksi dan reisolasi). Uji tantang dilakukan setelah 30 hari pemeliharaan (akhir pemberian imunostimulan), dengan cara menginfeksi ikan dengan bakteri aktif melalui penyuntikan intraperitoneum (i.p.) pada konsentrasi $10^{5} \mathrm{cfu} / \mathrm{ekor}$.

Parameter yang diamati meliputi total leukosit, diferensial leukosit, titer antibodi, performan ikan dan gejala klinis, serta tingkat sintasan ikan setelah diuji tantang. Total leukosit dihitung dengan hemasitometer Neubauer menurut metode Blaxhall dan Daisley (1973) dalam Wedemeyer dan Yasutake (1977). Pengamatan diferensial leukosit dilakukan dengan membuat preparat ulas darah dan dihitung menurut metode Lucky (1977). Pengukuran titer antibodi pada serum darah ikan dilakukan menurut metode Carpenter (1975); sedangkan pengamatan performan dan gejala klinis dilakukan setiap hari. Pengamatan gejala klinis dan mortalitas ikan uji setelah uji tantang dilakukan selama satu minggu. Ikan uji yang mati dan memperlihatkan gejala klinis akibat infeksi bakteri diperiksa secara mikrobiologis untuk mengetahui penyebab kematian.

\section{HASIL DAN PEMBAHASAN}

Dari hasil penelitian ini diperoleh nilai total leukosit, diferensial leukosit dan titer antibodi serum darah ikan sebelum dan sesudah pemberian imunostimulan. Juga diketahui performan ikan uji selama pemeliharaan, gejala klinis dan tingkat sintasan ikan setelah diuji tantang dengan bakteri $A$. hydrophila. Rata-rata total leukosit ikan uji yang dihitung sebelum perlakuan, akhir perlakuan dan setelah uji tantang dapat dilihat pada Gambar 1. 

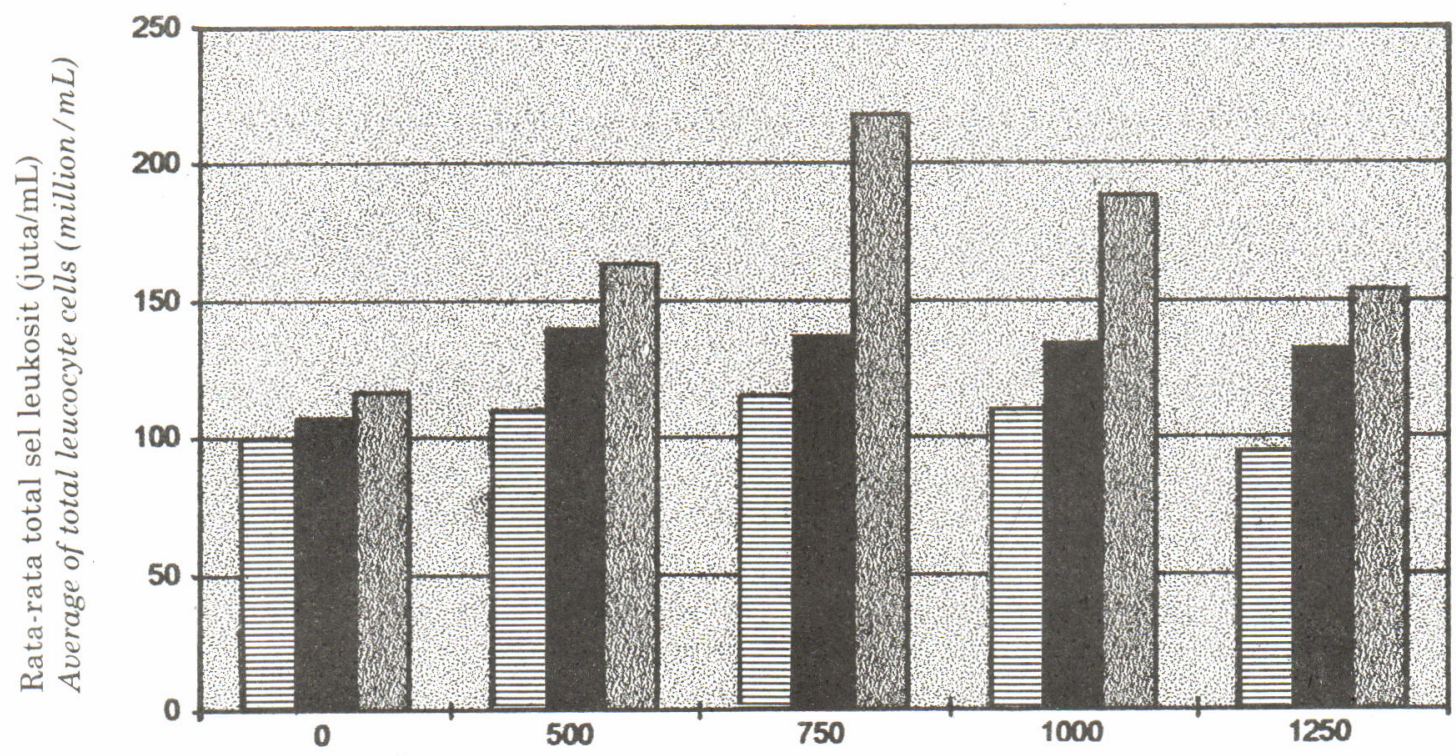

Dosis imunostimulan (mg/kg pakan) Immunostimulant dose ( $\mathrm{mg} / \mathrm{kg}$ feed)

Sebelum perlakuan Pre-treatment

\section{Setelah perlakuan} Post-treatment
Setelah uji tantang Post-challenge

Gambar 1. Rata-rata total leukosit ikan uji sebelum dan setelah perlakuan sebelum uji tantang serta setelah uji tantang dengan bakteri Aeromonas hydrophyla.

Figure 1. Average total leucocyte of test fish prior and after treatment before challenge and after challenge with Aeromonas hydrophila.

Nilai total leukosit pada Gambar 1 tersebut sesuai dengan standar yang dibuat oleh Chinabut et al. (1991), bahwa total leukosit ikan normal berkisar antara 20.000-150.000 sel/ $/ \mathrm{mm}^{3}$ darah. Total leukosit kelompok ikan perlakuan mengalami peningkatan besar setelah uji tantang. Gambar 1 juga memperlihatkan bahwa total leukosit meningkat baik pada kelompok kontrol maupun kelompok perlakuan, namun peningkatannya pada kelompok perlakuan rata-rata lebih tinggi dibandingkan dengan kelompok kontrol.

Pada kelompok perlakuan didapatkan nilai total leukosit terendah pada pemberian imunostimulan dosis $1250 \mathrm{mg} / \mathrm{kg}$ pakan, kemudian diikuti oleh dosis $500 \mathrm{mg} / \mathrm{kg}$ pakan. Rendahnya nilai total leukosit pada kedua perlakuan tersebut diduga karena pada dosis imunostimulan yang tinggi akan terjadi penekanan mekanisme pertahanan dan pada dosis yang rendah menjadi kurang efektif (Anderson, 1992). Selanjutnya Tizard (1988) menyatakan bahwa pemberian imunostimulan dosis tinggi ataupun rendah akan menjadi supresor, yaitu sel berfungsi untuk menekan respon sel B dan sel T terhadap antigen dengan mengeluarkan faktor supresor terlarut.

Pengamatan diferensial leukosit dilakukan dengan menghitung persentase neutrofil, limfosit, monosit dan trombosit pada awal dan akhir perlakuan serta setelah uji tantang dengan bakteri A. hydrophila. Hasil lengkap rata-rata diferensial leukosit dapat dilihat pada Gambar 2; 3; 4; dan 5, masing-masing untuk neutrofil, limfosit, monosit dan trombosit.

Persentase neutrofil cenderung meningkat selama perlakuan dan setelah diinfeksi dengan bakteri. Menurut Dellman dan Brown (1989), umumnya jumlah neutrofil meningkat pada saat terjadi kasus penyakit bakteri karena neutrofil keluar dari pembuluh darah menuju daerah infeksi. Fungsi utama neutrofil adalah penghancuran bahan asing melalui proses fagositik, yaitu kemotaksis di mana sel bermigrasi menuju partikel, perlekatan partikel pada sel, penelanan partikel oleh sel dan penghancuran partikel oleh enzim lisosom di dalam fagolisosom (Tizard, 


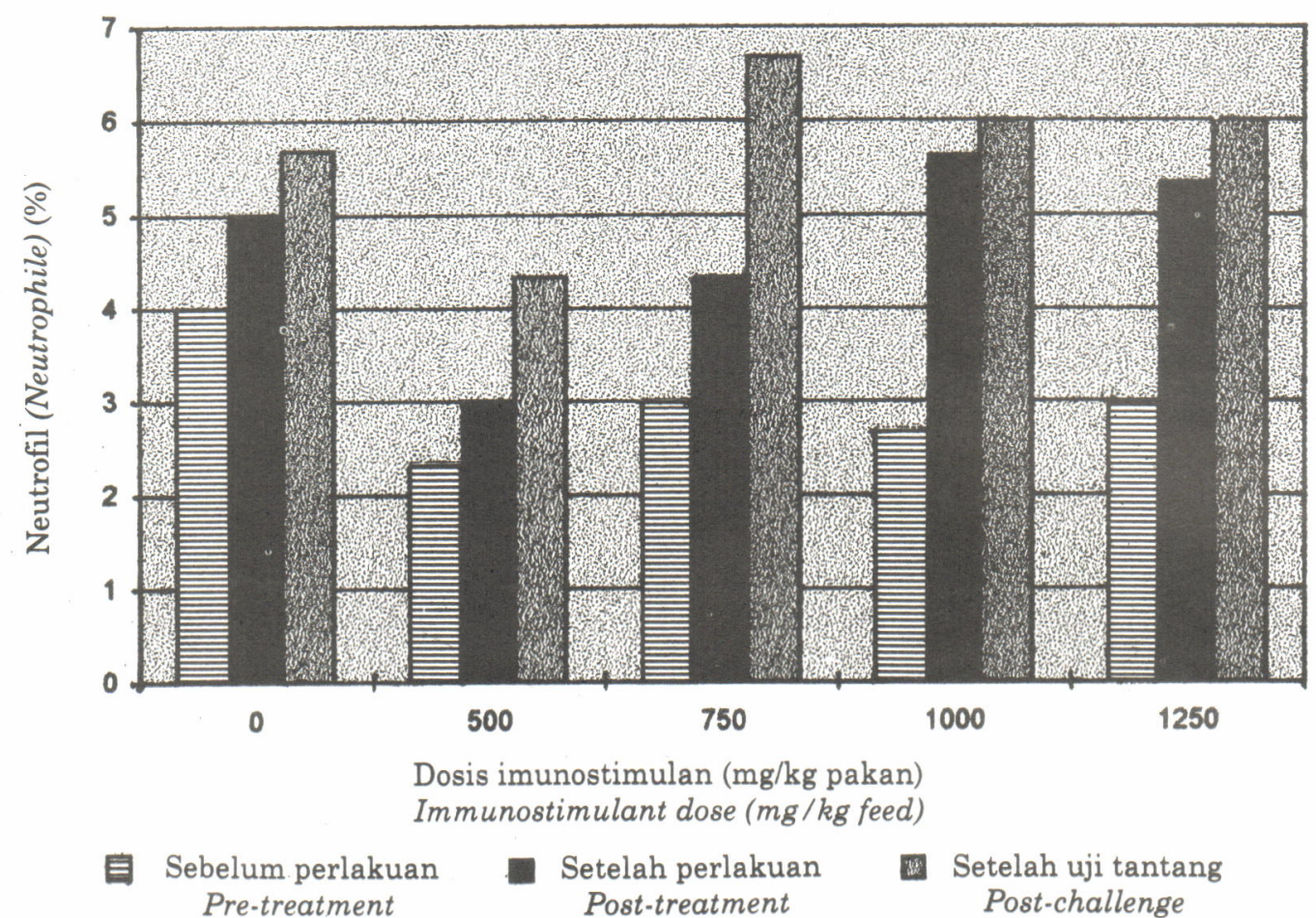

Gambar 2. Diferensial leukosit (persentase rata-rata neutrofil) pada lele Dumbo.

Figure 2. Leucocyte differential (average percentage of neutrophil) of African catfish.

1988). Keluarnya neutrofil dari pembuluh darah pada saat terjadinya infeksi disebabkan karena adanya pengaruh rangsangan kimiawi eksternal atau kemotaksis.

Jumlah neutrofil pada pengamatan didapatkan nilai yang rendah, meski terjadi peningkatan. Hal ini disebabkan karena proporsi neutrofil dalam populasi leukosit hanya sekitar 6-8\% (Roberts, 1978). Peningkatan jumlah neutrofil setelah uji tantang berhubungan dengan responnya terhadap infeksi, yaitu membunuh bakteri dan membersihkan pecahan jaringan. Neutrofil ini merupakan garis pertahanan pertama yang bergerak cepat ke arah bahan asing dan menghancurkannya, tetapi tidak mampu bertahan lama. Biasanya neutrofil hanya nenghancurkan tuntas setiap bahan asing yang ditelan dan tidak mengolah antigen sebagai persiapan guna disajikan pada sel peka antigen (Tizard, 1988). Lebih lanjut Lucky (1977) menjelaskan bahwa pada saat terjadi infeksi, jumlah neutrofil meningkat $6-7 \%$.

Limfosit berfungsi menyediakan zat kebal untuk pertahanan tubuh (Dellman dan Brown, 1989), ditemukan dalam jumlah yang besar meskipun pada saat infeksi terjadi penurunan. Tingginya kadar limfosit ini disebabkan karena proporsinya dalam leukosit besar. Penurunan jumlah limfosit setelah uji tantang diduga karena kegiatannya dalam menyediakan zat kebal terganggu oleh masuknya infeksi. Dalam keadaan ini limfosit dibantu monosit dan neutrofil. Hasil lengkap pengamatan diferensial leukosit dapat dilihat pada Gambar 3.

Persentase monosit didapatkan meningkat selama perlakuan dan setelah diinfeksi bakteri (Gambar 4). Peningkatan persentase monosit ini diduga karena fungsinya sebagai makrofag dan memfagosit benda-benda asing yang masuk ke dalam tubuh (Roberts, 1978). Fagositosis oleh makrofag merupakan proses yang sama seperti pada neutrofil. Makrofag tertarik secara kemotaktik tidak hanya pada produk mikroorganisme dan produk reaksi kebal, tapi juga pada faktor sel yang rusak, terutama neutrofil yang rusak. Jadi neutrofil tidak hanya mencapai dan menyerang bahan asing, tetapi menjelang kematian membantu meningkatkan pengumpulan makrofag di tempat infeksi. Antigen dihancurkan di dalam makrofag dengan cara yang sama seperti pada neutrofil. Makrofag ini mampu memiliki aktivitas 


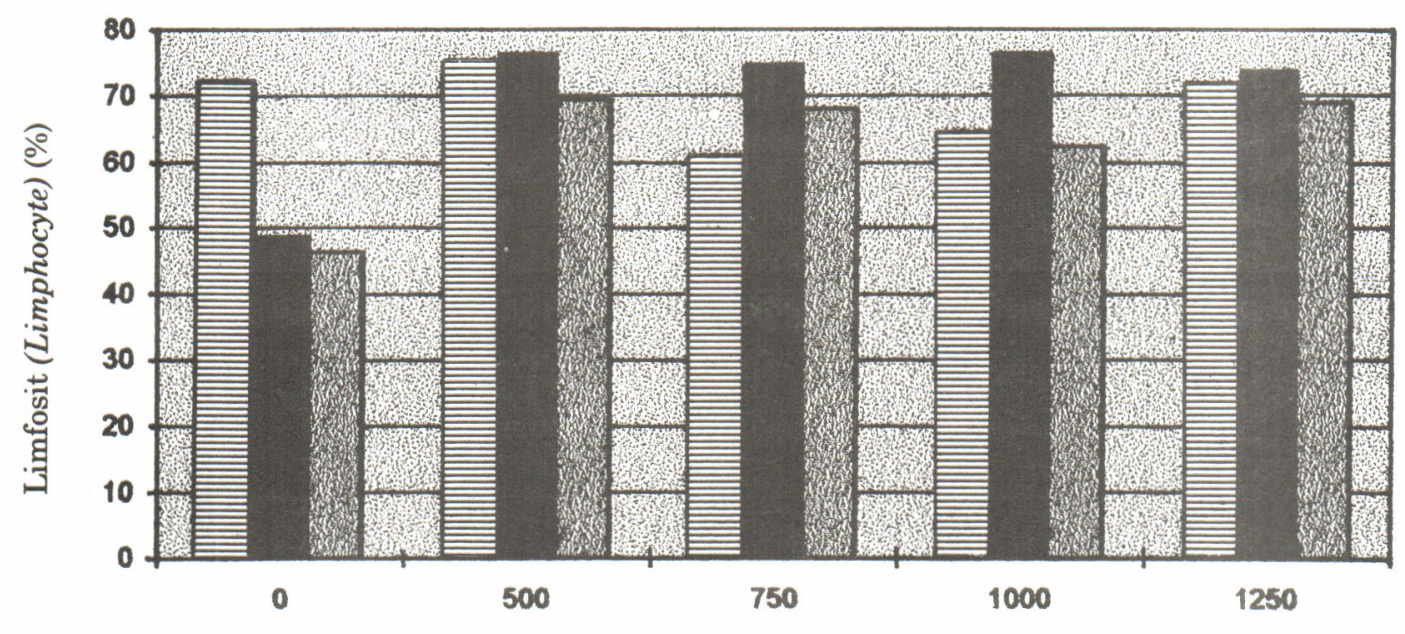

Dosis imunostimulan (mg/kg pakan) Immunostimulant dose ( $\mathrm{mg} / \mathrm{kg}$ feed)
E Sebelum perlakuan Pre-treatment
Setelah perlakuan Post-treatment
- Setelah uji tantang Post-challenge

Gambar 3. Diferensial leukosit (persentase rata-rata limfosit) pada lele Dumbo.

Figure 3. Leucocyte differential (average percentage of limphocyte) of African catfish.

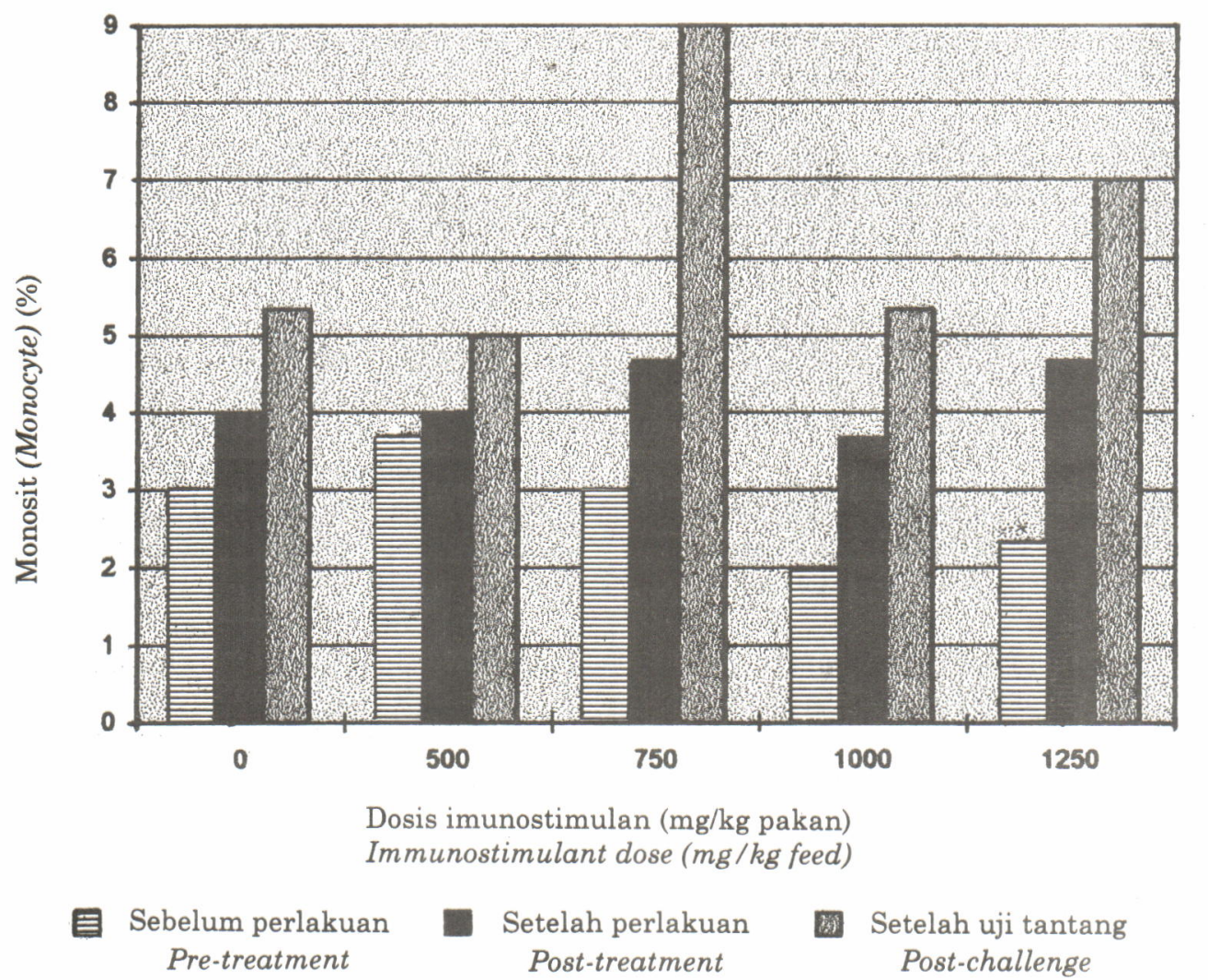

Gambar 4. Diferensial leukosit (persentase rata-rata monosit) pada lele Dumbo.

Figure 4. Leucocyte differential (average percentage of monocyte) of African catfish. 


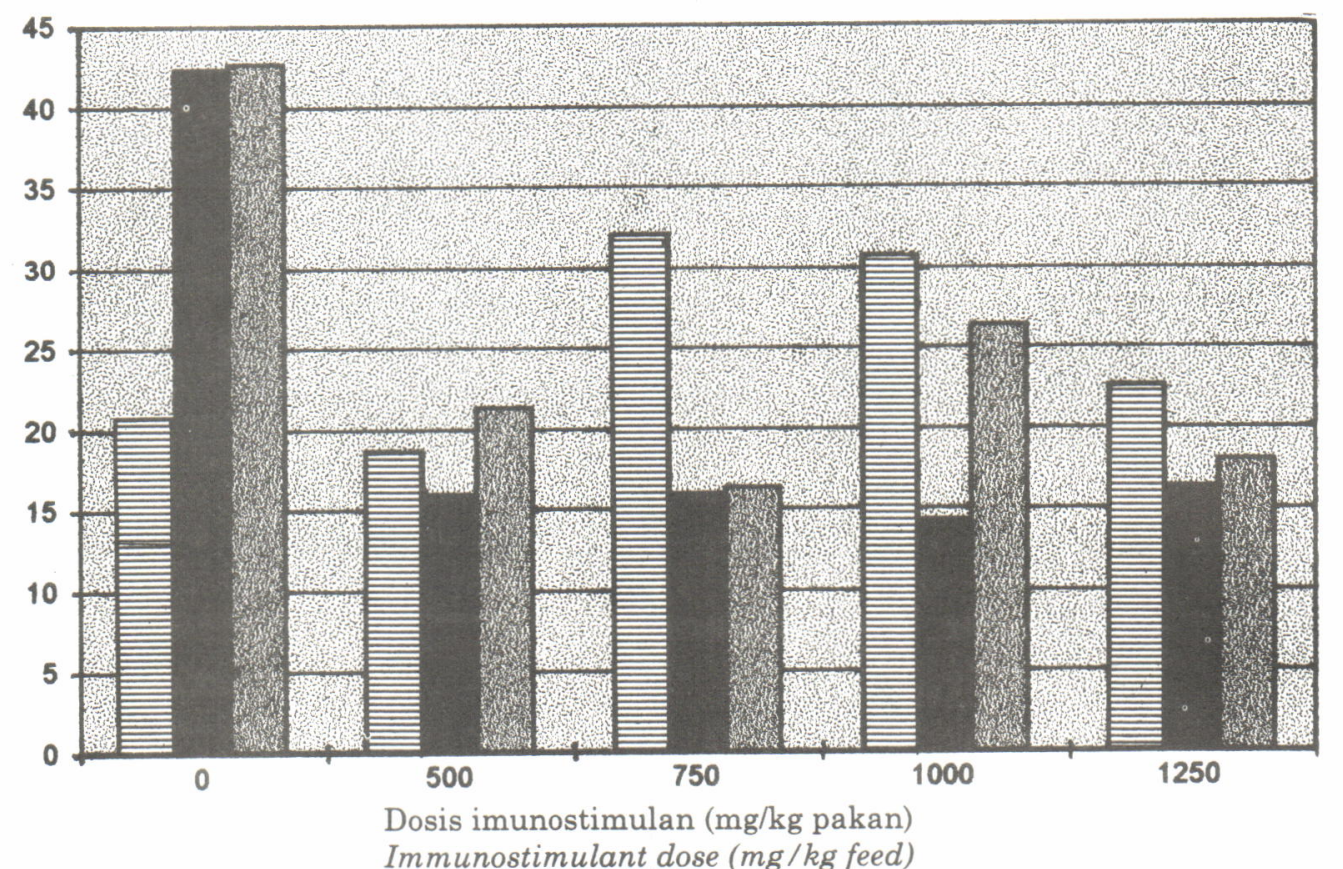

Sebelum perlakuan Pre-treatment
Setelah perlakuan Post-treatment
Setelah uji tantang Post-challenge

Gambar 5. Diferensial leukosit (persentase rata-rata trombosit) pada lele Dumbo.

Figure 5. Leucocyte differential (average percentage of thrombocyte) of African catfish.

fagositik yang tahan lama, mengolah antigen dalam persiapan untuk tanggap kebal dan memberi kontribusi langsung pada perbaikan jaringan yang rusak dengan membuang jaringan yang mati, yang sedang mengalami kematian dan yang rusak. Rendahnya kadar monosit disebabkan karena proporsinya dalam leukosit hanya sekitar $0,1 \%$ (Roberts, 1978), akan tetapi dapat meningkat sekitar $38 \%$ dalam waktu singkat bila terjadi infeksi (Lucky, 1977).

Persentase trombosit pada pengamatan setelah uji tantang bakteri umumnya meningkat (Gambar 5). Hal ini diduga karena perannya untuk menutup luka (Chinabut et al., 1991). Lebih lanjut Rastogi (1977) menjelaskan bahwa jumlah trombosit umumnya meningkat setelah terjadi luka atau bila terjadi hemoragi.

Titer antibodi ikan mulai diukur pada minggu ke-2 setelah perlakuan. Hal ini didasarkan pada kenyataan bahwa ikan biasanya membutuhkan waktu laten 2 minggu untuk melakukan tanggap kebal dalam bentuk peningkatan produksi antibodi. Rata-rata pengukuran antibodi dapat dilihat pada Gambar 6. Titer antibodi mulai meningkat pada minggu ke-3 dan mencapai puncaknya pada minggu ke-4 dan ke-5, kemudian mulai menurun kembali pada minggu ke-6, yaitu setelah diinfeksi dengan bakteri $A$. hydrophila. Puncak titer antibodi pada perlakuan C (dosis glukan $750 \mathrm{mg} / \mathrm{kg}$ pakan) terjadi pada minggu ke-5, disusul oleh perlakuan D, B, E dan A.

Peningkatan produksi antibodi pada semua perlakuan terjadi pada minggu ke-3. Antibodi pada ikan biasanya mulai ada pada minggu ke-2 dan ke-3 (Anderson, 1974). Menurut Tizard (1988) antibodi terjadi karena adanya rangsangan antigen penginfeksi. Proses ini dimulai dengan penjeratan dan pencernaan antigen oleh makrofag yang berlangsung secara aktif. Makrofag ini kemudian akan memberikan rangsangan kepada sel limfosit untuk berproliferasi dan berdiferensiasi menjadi sel memori dan sel plasma yang akan menghasilkan antibodi. Puncak titer antibodi dimulai pada minggu ke-4 pada setiap perlakuan, seperti yang diamati Hanifa (1993).

Peningkatan dosis pemberian imunostimulan tidak selalu memberikan hasil yang optimal. Hal ini sesuai dengan pendapat Nitimulyo dan Triyanto (1990) yang mengatakan bahwa peningkatan dosis imunostimulan tidak selalu se- 


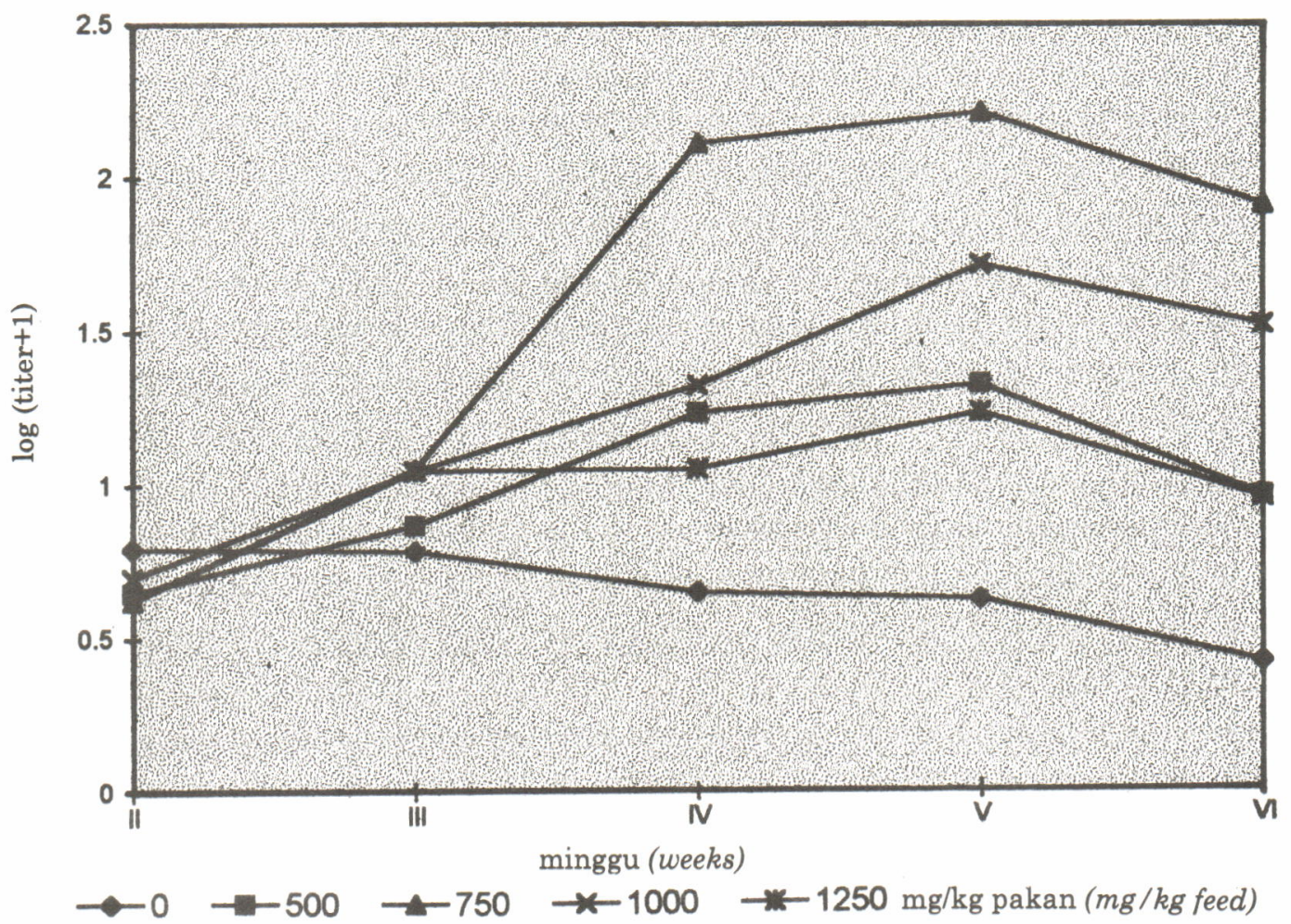

Gambar 6. Rata-rata titer antibodi lele Dumbo.

Figure 6. Average antibody titer of African catfish.

banding dengan kenaikan titer, karena pada pemberian dosis terlalu tinggi dan rendah hanya dihasilkan sedikit kompleks kebal.

Pada minggu ke- 6 terjadi penurunan produksi antibodi. Hal yang sama juga didapatkan pada penelitian Hanifa (1993). Penurunan produksi antibodi ini diduga karena adanya infeksi bakteri Aeromonas hydrophila yang masuk ke dalam tubuh. Oleh sebab itu, mekanisme pertahanan tubuh dipusatkan pada daerah terjadinya infeksi. Selain itu, penurunan produksi antibodi juga disebabkan karena pada saat terjadinya infeksi, limfosit yang berfungsi untuk menghasilkan antibodi mengalami penurunan karena aktivitasnya terganggu. Pada ikan kontrol terjadi penurunan antibodi mulai minggu ke-4 sampai minggu ke- 6 . Hal ini disebabkan karena tidak adanya glukan dalam pakannya yang dapat merangsang limfosit sel B untuk memproduksi antibodi.

Gejala klinis pada masing-masing ikan perlakuan dan kontrol setelah uji tantang dengan bakteri $A$. hydrophila menunjukkan gejala yang sama. Gejala yang timbul adalah peradangan kulit, sirip patah, perubahan tingkah laku ikan dan respon makan yang menurun.
Pada umumnya peradangan pada punggung dan pangkal sirip mulai tampak pada hari ke-2 setelah penyuntikan bakteri, yang masih tetap terlihat pada hari ke-3 pengamatan. Pada hari ke-5 sebagian ikan perlakuan $\mathrm{C}$ dan $\mathrm{D}$ telah mulai mengalami proses penyembuhan, ikan perlakuan B dan E pada hari ke-6 dan ke-7, sedangkan ikan kontrol sebagian baru mengalami proses penyembuhan pada hari ke-7. Ikan kontrol mengalami sirip patah paling banyak.

Pada pengamatan perubahan tingkah laku umumnya semua ikan perlakuan gerakannya lambat, lemas dan sebagian ikan perlakuan mengapung di permukaan pada hari ke-1 setelah penyuntikan. Pada hari ke-3 gerakan ikan perperlakuan telah normal, kecuali pada sebagian ikan kontrol yang aktif kembali pada hari ke-4. Pada hari ke-1 dan ke-2 setelah penyuntikan bakteri, tidak ada respon makan untuk semua ikan perlakuan. Respon makan ikan perlakuan C mulai ada pada hari ke-3 dan selanjutnya ikan kembali aktif makan pada hari ke-5. Ikan perlakuan B, D, E dan kontrol mulai menunjukkan respon makan pada hari ke-4 dan kembali aktif pada hari ke-5 dan ke-6. 


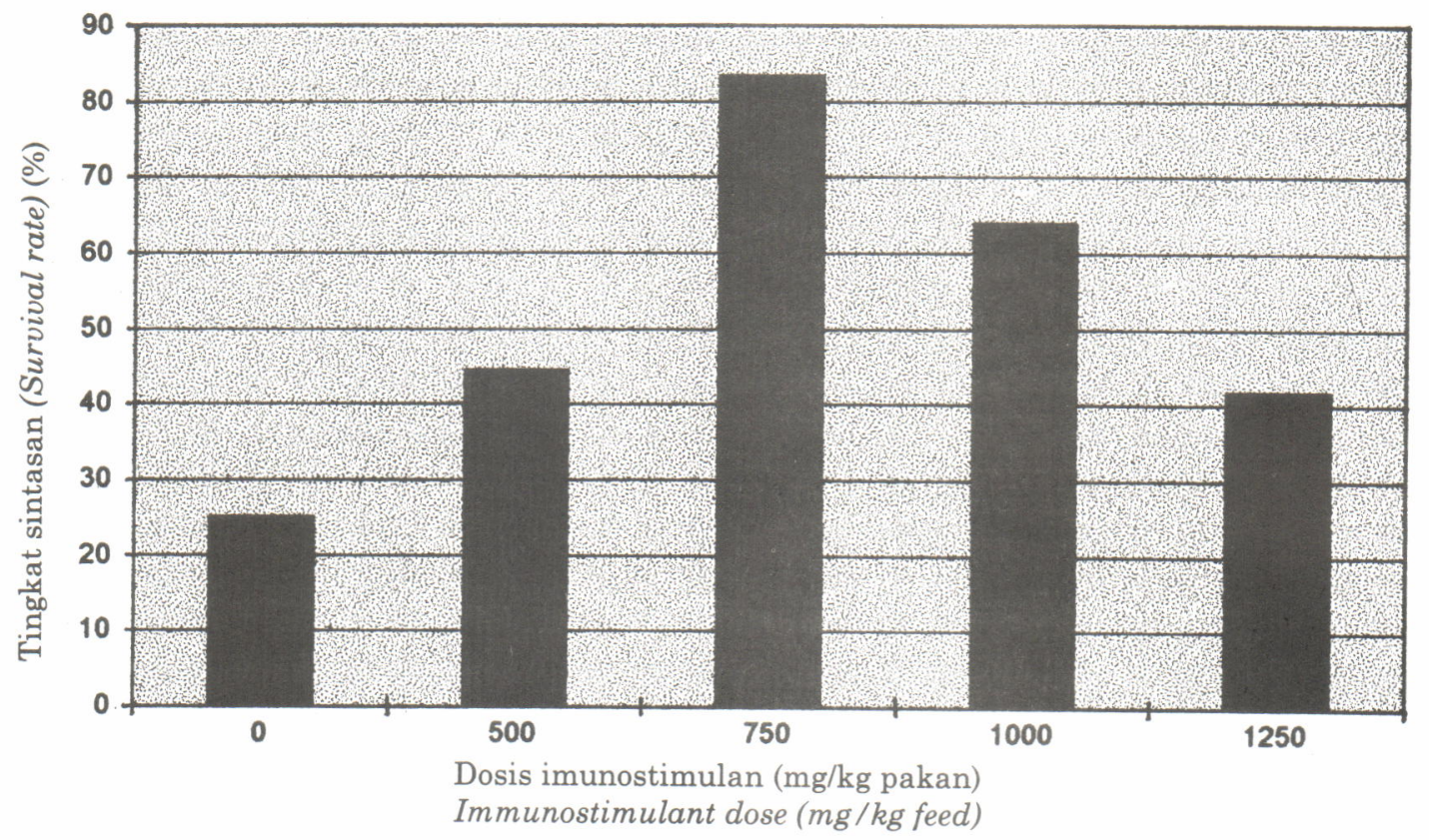

Gambar 7. Tingkat sintasan (\%) lele Dumbo sesudah uji tantang dengan Aeromonas hydrophila. Figure 7. Survival rate (\%) of African catfish after challenged with Aeromonas hydrophila.

Pada semua ikan perlakuan, gejala klinis terjadi pada hari ke-2 setelah uji tantang. Keadaan ini dimulai dengan timbulnya pembengkakan pada daerah bekas suntikan. Tizard (1988) mengatakan bahwa bila suatu mikroorganisme atau bahan asing lainnya memasuki jaringan, pertahanan tubuh dimobilisasi dan diarahkan ke tempat terjadinya serangan yang menyebabkan terjadinya perbarahan. Tanda utama perbarahan adalah kemerahan, bengkak dan sakit. Bengkak pada daerah suntikan ini kemudian berkembang menjadi tukak, yaitu pecahnya kulit permukaan.

Proses penyembuhan yang lebih cepat pada ikan perlakuan dibandingkan dengan ikan kontrol, kemungkinan disebabkan oleh adanya glukan yang merangsang makrofag untuk lebih meningkatkan kemampuannya dalam membunuh bakteri. Hasil reisolasi bakteri menunjukkan bahwa bakteri yang menginfeksi adalah bakteri Aeromonas hydrophila.

Sintasan ikan lele dumbo setelah uji tantang bakteri Aeromonas hydrophila pada setiap perlakuan mengalami penurunan (Gambar 7). Sintasan tertinggi dicapai pada penambahan glukan sebesar $750 \mathrm{mg}$ glukan/kg pakan (per- lakuan C) dan sintasan terendah terjadi pada ikan kontrol (perlakuan A). Hal ini menunjukkan bahwa penggunaan glukan dapat menurunkan total mortalitas ikan. Raa et al. (1992) dalam penelitiannya pada respon ikan salmon (Salmo salar L) terhadap infeksi bakteri $V$. salmonicida menghasilkan bahwa penambahan glukan dalam pakan sebesar $1000 \mathrm{mg}$ glukan/kg pakan dapat menurunkan mortalitas ikan sebesar $40 \%$ dan terhadap $V$. anguillarum sebesar $20 \%$.

Pada dosis glukan yang tinggi (1250 mg glukan/kg pakan) diperoleh tingkat sintasan yang rendah. Demikian pula pada dosis glukan yang rendah (500 mg/kg pakan). Hal ini didukung oleh penelitian Robertsen et al. (1990) yang melakukan penyuntikan glukan dengan dosis rendah ternyata menghasilkan efek perlindungan yang menurun dari hari ke-7 setelah penyuntikan. Robertsen et al. (1990) mengatakan, bahwa pada dosis glukan yang tinggi terkadang menggambarkan kematian yang lebih tinggi daripada ikan kontrol. Lebih lanjut dijelaskan pada saat sejumlah besar glukan masuk ke dalam tubuh, maka glucan tersebut akan memberi rangsangan kepada sel-sel fagositik ikan yang melebihi kemampuannya sehingga menurunkan aktivitas- 
nya dalam membunuh bakteri dan bahan asing lainnya. Pada dosis rendah, rangsangan yang diberikan glukan kepada makrofag tidak mencukupi kebutuhannya dalam memfagosit dan memusnahkan bakteri.

Uji analisis ragam sintasan ikan lele dumbo setelah uji tantang bakteri $A$. hydrophila, didapatkan bahwa penambahan glukan yang berbeda dalam pakan menyebabkan perbedaan sintasan ikan lele dumbo $(\mathrm{P}<0,05)$. Penambahan glukan dalam pakan komersial (X) menyebabkan respon sintasan $(\mathrm{Y})$ berpola kuadratik dengan persamaan sebagai berikut:

$$
Y=20,91+0,13 X-840 \times 10^{5} X^{2}
$$

Berdasarkan persamaan kuadratik tersebut, sintasan optimum ikan lele dumbo setelah diinfeksi bakteri $A$. hydrophila dicapai pada penambahan glukan dalam pakan sebesar 773,81 $\mathrm{mg} / \mathrm{kg}$ pakan.

\section{KESIMPULAN}

a. Secara klinis tidak tampak perbedaan gejala klinis ikan setelah penyuntikan bakteri Aeromonas hydrophila baik pada ikan kontrol maupun perlakuan, walaupun kelompok ikan perlakuan cenderung mengalami proses penyembuhan yang lebih cepat, yaitu pada hari ke-5 dan ke-6 setelah penyuntikan dibandingkan dengan ikan kontrol.

b. Leukosit meningkat dari awal hingga akhir penelitian dan jumlah total leukosit tertinggi dicapai oleh penambahan $750 \mathrm{mg}$ glukan $/ \mathrm{kg}$ pakan.

c. Pengukuran titer antibodi mencapai puncak pada minggu ke-5 dan menurun pada minggu ke-6. Dilihat dari titer antibodi, pemberian 750 mg glukan/kg pakan memberi hasil optimal.

d. Analisis secara statistik menunjukkan bahwa penambahan glukan optimum dalam pakan adalah sebesar $773,81 \mathrm{mg}$ glukan/kg pakan.

\section{DAFTAR PUSTAKA}

Anderson, D.P. 1974. Fish immunology. THF Pub. Inc. Ltd. Hongkong. 239 hal.
Anderson, D.P. 1992. Immunostimulants, adjuvants, and vaccine carriers. In fish application to aquaculture. Annual Rev. of Fish Diseases, 2: 281-307.

Carpenter, P.L. 1975. Immunology and serology. Third Ed. W.B. Saunders Co. Philadelphia 345 hal.

Chinabut, S.; Limsuwan and P. Kitsawar. 1991. Histology of the walking catfish (Clarias batrachus). AAHRI. Bangkok. Thailand. 96p

Dellman, H.D. and E.M. Brown. 1989. Buku teks histologi veteriner. Penerbit Universitas Indonesia. Jakarta. 279 hal.

Fletcher, T.C. 1982. Non-specific defence mechanisms of fish. Dev. Comp. Immunology. 2: 123.

Hanifa, M. 1993. Tanggap kebal terhadap antigen "Ich" pada ikan lele dumbo (Clarias gariepinus) setelah imunisasi dengan antigen Tetrahymena pyriformis dan imunostimulan. Skripsi. Universitas Nasional. Jakarta. 53 hal.

Nitimulyo, K. H. dan Triyanto. 1990. Sistem pertahanan dan serologi penyakit ikan. Pelatihan karantina ikan. BPLP Ciawi, Bogor. 29 hal.

Lucky, Z. 1977. Methods for the diagnosis of fish diseases. Amerind Publishing Co. PVT. LTD. New Delhi, Bombay, Calcuta, New York.

Raa, J., Roerstad, G., Engstad, R., and B. Robertsen. 1992. The use of immunostimulants to increase resistance of aquatic organisms to microbial infections In: M. Shariff, R.P. Subangsihe \& J.R. Arthur (eds). 1992. Diseases in Asian aquaculture I. Fish Health section, Asian Fisheries Society, Manila, Philliphines.

Rastogi, S.C. 1977. Essential of animal physiology. Wiley Eastern Limited. New Delhi, Bangalore, Bombay, Calcuta. hal 204-223.

Roberts, R.J. 1978. Fish pathology. Iowa State University Press, Ames, Iowa. hal 3-10.

Robertsen, B.; G. Roersted; R. Engstad and J. Raa. 1990. Enhancement of non-specific diseases resistance in Atlantic salmon (Salmo salar L) by a glucan from Saccharomyces cerevisiae cell-walls. J. of Fish Diseases. 13: 391.

Rukyani, A. and K.H. Nitimulyo. 1993. Fish vaccination and its prospect for disease control in Indonesia aquaculture. IARD Journal 15(4): 81-85

Rukyani, A.; Taukhid dan K.H. Nitimulyo. 1995. Imunisasi maternal: suatu teknik baru dalam penanggulangan penyakit ikan. Jurnal Litbang Pertanian, XIV(1): 1-5 
Supriyadi, H. and A. Rukyani. 1990. Imunopropilaksis dengan cara vaksinasi pada usaha budidaya ikan dalam Rukyani et al. (1990) Seminar Nasional II Penyakit Ikan dan Udang Balai Penelitian Perikanan Air Tawar. Bogor

Tizard, I. 1988. An introduction to veterinary immunology. Penterjemah P. Masduki dan S. Hardjosworo.
Pengantar imunologi veteriner. Universitas Airlangga. Surabaya. 197 hal.

Wedemeyer, G. and W.T. Yasutake. 1977. Clinical methods for the assessment of the effects of environmental stress on fish health. United States Department of the Interior Fish and Wildlife Service. Washington, DC. 